InOdia $\quad \begin{aligned} & \text { InMedia } \\ & \text { The French Journal of Media Studies }\end{aligned}$

7.1. $\mid 2018$

Visualizing Consumer Culture

\title{
The Present(s) - Interdisciplinary Study Day
}

\section{Emilie Cheyroux}

\section{(2) OpenEdition}

\section{Journals}

Electronic version

URL: http://journals.openedition.org/inmedia/1524

DOI: 10.4000/inmedia.1524

ISSN: 2259-4728

\section{Publisher}

Center for Research on the English-Speaking World (CREW)

\section{Electronic reference}

Emilie Cheyroux, «The Present(s) - Interdisciplinary Study Day », InMedia [Online], 7.1. | 2018, Online since 20 December 2018, connection on 08 September 2020. URL : http://journals.openedition.org/ inmedia/1524; DOI : https://doi.org/10.4000/inmedia.1524

This text was automatically generated on 8 September 2020

(c) InMedia 


\title{
The Present(s) - Interdisciplinary Study Day
}

\author{
Emilie Cheyroux
}

1 The hyperactivity that characterizes our daily lives has become a trendy topic for those who preach the enjoyment of the present moment. Nothing seems to be harder to reach than a stable state of mindfulness in which thoughts about the past or the future are temporarily at bay. How could things be different? The definition of the living present is that it is constantly fleeting, enticing us to keep thinking forward. The issue at stake nevertheless does not so much lie in the objective and quantitative passing of time on which no one has control, as in its subjective apprehension. Being a human construct, time is apprehended in its linearity thus, the experience of the present can hardly escape the imprint of past experiences and the expectations of the future. The intrinsic link between the present, the past and the future is what makes the study of the present time difficult yet crucial, for the present is the only space of action.

2 In academia-whether in literature, social sciences, or linguistics-the present keeps intriguing researchers. The organizational team of the scholarly magazine Traitsd'Union (Université Sorbonne Nouvelle - Paris 3) made it the focus of its ninth edition, launched with a study day on April $10^{\text {th }}$ at Maison de la Recherche in downtown Paris. A publication devoted to publishing the work of young doctoral students, Traits-d'Union is a not only a springboard for research in the making, it also generates interdisciplinary insights on contemporary topics. The originality of the call for papers this year was its premise that there are several "presents," opening the door to the study of its different facets. Far from unsettling the participants, the fertile quality of the topic allowed for the organization of five different sessions dedicated to studying literature, photography, linguistics, visual culture and subjective experiences.

3 The first session, "Hantise d'un présent pluriel en littérature," began with two talks inquiring about the plural meanings obscured by the use of the present tense in literature. Cécile Rousselet, a student in comparative literature, set out to study two novels published in 1999, War and War by Vladimir Sorokine and Blue Lard by Laszlo Krasznahorkai, and explored the influence of the post-soviet context on the writing of 
dystopias. She discussed the entanglement between the present, the past, and the future using the concept of diffraction. She argued that in these novels, both space and time undergo diffraction as they are haunted by visions of the past and expectations about a possible utopian future. For Alice Desquilbet, and her analysis of Sony Labou Tansi's novel The Seven Solitudes of Lorsa Lopez (1995), there is no such thing as a future for the inhabitants of Valencia. Using the concept of Anthropocene-a neologism coined to identify a new era during which humans have started having a detrimental impact on the earth-she showed that the present tense can be used to reveal the finite quality of time for human beings. Her presentation resonated with current issues, especially the part in which she explained how in the novel the Earth is personified and warns the people of the upcoming murder of a woman. The impossibility of going back in time brings about "a present with no future" for which human beings should take full responsibility.

The second session, "Arrêt sur images," strove to highlight the struggle to capture the present moment for writers and photographers. Jeanne Castillon talked about Claude Simon, a French novelist who also published an album entitled Photographies 1937-1970. She showed that his interest for this medium came from his realization of the impossibility for writers to seize the moment: when memory is involved, the past can only be recreated and interpreted from a present state that fails to capture the essence of the past moment. Photography then seems to have come as a soothing tool for the writer to momentarily stop the constant passing of ungraspable moments. This almost anxious apprehension of time was absent from the following doctoral student's presentation. In his investigation of Seascapes, a series of photographs by Japanese photographer Hiroshi Sugimoto, Alexandre Melay showed how the artist invites his audience to see his minimalist pictures of the sea as an expression of infinity. Stressing the influence of the Zen philosophy in Japan, he drew attention to the link between the artist's work and the practice of meditation, encouraging people to see wealth in emptiness.

5 The last session of the morning, "Constructions linguistiques des présent(s)," featured three speakers who demonstrated that the field of linguistics is intrinsically interdisciplinary. Ailin Nacucchio started with a presentation discussing the notions of departure and continuity in the New Right speeches in Argentina and Venezuela. Drawing from discourse analysis methods, he set out to explore the rhetorical strategies used by two leaders, Mauricio Macri and Enrique Capriles. The use of the present tense was analyzed to highlight the men's desire to stand out in the political landscape. The talk was followed by the analysis of the present tense in the judicial context by Anton Osminkin who demonstrated the universal character of the present tense in four major documents: the Russian Federation Constitution, the United Nations Charter, the Treaty on the Eurasian Economic Union, and The Civic Code of the Russian Federation. The thousand occurrences that he studied in English, Russian, and French underlined the implicit meaning of obligation and prescription and allowed him to argue the existence of a "judicial present." Finally, Georgeta Cristian addressed the issue of polyphony in David Wahl's theatrical piece Histoire spirituelle de la danse, also comparing occurrences in French and Romanian. Using the French text and theatrical performance as well as the subheads of the Romanian show that took place on September 30,2017, she studied the different presents according to their contexts of use, thus linking theater and translation studies. 
The afternoon started with a session around the theme of visual culture entitled "Contemporanéités et culture visuelle." In the field of media studies, Diego Gachadouat-Ranz, a former choreographer, set out to probe the relationship between film and the experience of the present in Elephant (Gus Van Sant, 2003). While focusing on the embedded relationship between the present and its past and future projections, he analyzed the different strategies Van Sant uses to create the experience of the present for the audience. According to him, borrowings from photography, slow motion, and repetition fail to genuinely seize the present moment. He argued that the recreation of video games rambling scenes during which the player walks forward crystalizes the present moment and manages to postpone the inevitable mass shooting that occurred at Columbine. Heloise Van Appelghem also addressed a thorny and very current issue that ties in the controversial context surrounding the sexual assaults and harassment cases brought to light after the Weinstein scandal. She showed how the recent "Time's Up" movement allowed for a new reading of gender inequality, on screen and in society, and a new evaluation of movies and directors which were acclaimed in the past. Using gender and cultural studies, her presentation linked women's lack of representation and demeaning portrayals to equality demands, emphasizing the updated readings of movies according to the present context. She sided with scholars arguing that movies are not just fiction but can teach us about society's habits, however detrimental they might be. Finally, Marcela Rivas-Jamett went back in time to study the portrayal of death in the paintings of nineteenth century Spain. She analyzed two pieces: They still say fish is expensive by Joaquin Sorolla y Bastida, and A Disaster by Luis Jimenez Aranda. Linking aesthetical and social analysis, she showed how the use of light and the budding techniques of impressionism comment on the social realities surrounding dangerous and marginalized jobs. She demonstrated that by "presentifying" death, the painters engage the audience on social issues.

7 The study day ended with three presentations exploring the way we experience the present time, in a session entitled "Vivre le présent." Valentine Prouvez explained the role of our memory and of our memories. Mixing considerations from biology, psychoanalysis and philosophy, she discussed the non-linear conception of time for human beings and the way the past, the present, and the future are used to create one's identity. The influence of our minds was also at the core of Léa Maroufin's presentation. Her case study, that of the facsimile of the Chauvet cave, highlighted the key role of imagination for the visitors. The cave being a reconstruction of the original one, the human experience is based on the visitors' capacity to create a narrative based on their imagination. Her analysis relied on ethnographic field research and focused on the visitors' capacity to imagine a prehistorical past that is sometimes disturbed by elements that remind of the artificiality of the cave. Géraldine Moreau, the last participant, also conducted field research. She organized a qualitative study of apprenticeship in which she observed the paradoxical and contradictory use of time. Indeed, she argued that time acquires a texture that is molded according to the goals of the different classes given to students of cabinet-making and corporeal mime. Time is either urgent and meant to teach gestures quickly or considered a long process and the true condition to gain experience. The three presentations thus confirmed that there are different presents that are as diverse as human experiences. 
8 The day ended with a cocktail to celebrate the young scholars and the launch of the eighth issue of the magazine, around the theme of crossed fertilization. It is this latter word that stays in mind thinking about Traits-d'Union, whose specificity is to bridge methods and fields in order to explore a wide range of topics. The study of the present(s) proved to be as complex yet as interesting as advertised. The different presentations offered material to ponder about our use of time and its malleability. The upcoming articles which will be published in the $9^{\text {th }}$ edition of the magazine next spring will undoubtedly be an important contribution to the diverse fields united on this study day.

\section{AUTHOR}

\section{EMILIE CHEYROUX}

Emilie Cheyroux holds a PhD from Université Sorbonne Nouvelle - Paris 3. Her dissertation focuses on the strategies implemented by Cine Las Americas International Film Festival (Austin, Texas) to deconstruct stereotypes about Latinos and reconfigure visual, cognitive, geographical, and interactional habits in the Texan capital. She teaches English for the French Department of Education as a fully-certified teacher, as well as US History and Culture for master's degree students at Université Sorbonne Nouvelle - Paris 3. 